\title{
EXAMINATION OF DEVELOPMENT-AIMED SPATIAL DIVISION SYSTEMS IN HUNGARY
}

\author{
Lilla Aldorfai-Czabadai, Gyorgy Aldorfai, Zoltan Topa \\ Szent Istvan University, Hungary \\ aldorfaine.czabadai.lilla@gtk.szie.hu, aldorfai.gyorgy@gtk.szie.hu, topa.zoltan@gtk.szie.hu
}

\begin{abstract}
Dividing the area of a country into smaller units is required by multiple national development goals. The most basic territorial demarcations are based on natural borders; however, the role of pre-determined administrative borders is crucial as well. We can observe larger and smaller (micro and macro) territorial units in both cases, and this fact can influence the implementation. As an example, we can mention the methodology of the LEADER areas, the designation of urban agglomeration areas, urban regions or disadvantaged areas. According to the European Union and national commitments every territorial unit in different spatial levels must have development plans or concepts; however, after a while these documents are getting more and more difficult to manage and compare, because of the spatial overlapping. Another reason could be, as mentioned above, the very high level of diversity of these territorial units. This matter becomes even more complex considering the fact that there is usually more than only one development plan for a spatial unit. Our study will result in the presentation of the various types of spatial units and the development notions, concepts connected to them, thus we could see the roots of the outlined problems and issues. In relation with the highlighted good examples we would like compare the applied methodologies with the existing division systems in Hungary. In our research, besides the presentation of the different spatial unit types (districts), we would like to find out if it is possible to create a new, multivariate-method based spatial classification system which could result an effective territorial system for development policies.
\end{abstract}

Keywords: spatial division, district, regional development, methodology, categorisation.

\section{Introduction}

Regarding to the division of space and creation of spatial levels, and related to the economic geographic approach and regional research, space consists of unique subsystems, and therefore it can be divided into parts with unique characteristics. These spatial unites can most commonly be analysed, however it is also an important prerequisite that the certain units have an internal spatial nature themselves; therefore, they are not homogenous inside and they should not be treated as onedimensional units. In order to can investigate the chosen unit's spatial processes, we can create our own examination ("test") area. In most of the cases it means an already existing, administrative or statistical system, but often the creation of the optimum territorial division became the subject of the research. It means that the analyses can be done within administrative borders, but in order to the proper implementation of our examination we can determine an own spatial division, which often appears as a system of economic districts [1]. These theories applied in most of the special territorial researches resulted in a different type of development-aimed spatial division systems shown in the present study.

\section{Materials and methods}

In our research we mostly apply literature review and document analyses in order to gain information from the valid spatial systems in Hungary. We can say that several studies written by experts and researchers deal with designation of different development areas, but most of them focus on one special issue, the complex, multivariate approaches are missing. Therefore, we would like to outline the main spatial division system, which originates from official (national, governmental) sources. Including, but not limited we look over the concerning National Development Concepts, regulations and acts from the past decades, which could draw a relevant picture about the current situation in Hungary.

\section{Results and discussion}

We can see an example for economic districts in the United States. The Economic Development Administration (EDA) as a federal government agency with six regional offices is operating for sustainable, locally-driven economic development purposes. The designation process follows the principles of the agency; that area (region) could be an Economic Development District, which has a Comprehensive Economic Development Strategy (created, coordinated and driven by individuals, 
non-governmental organizations, local governments and private industries) and at least one geographical area within its desired boundaries. EDA is providing funds in a wide range; for example, between 2012 and 2016 the three main themes of the expenditures were in the fields of infrastructure, capacity building and construction. One-third of its funds went to urban areas and two-thirds of its funds have been utilized in rural areas [2]. This issue is very topical in the European concern as well the distribution rate of the funds between urban and rural areas is a highly contested question.

Special forms of economic districts which are indeed development-aid are Special Economic Zones (SEZ) or Free Economic/Enterprise Zones (FEZ). We can define SEZs as "a part of the national territory of a country with special regime, which is a system of general benefits available to SEZ residents (including trade benefits, tax exemptions, financial incentives and administrative benefits)". Beyond the strictly business-based aims, a typically common goal is promotion of the regional development. All over the world more than 5000 SEZ exist; the leading nations are China (over 100), the USA (over 50), UAE (42), and Russia (25). In Europe Ireland and Poland are in a good position, the former has 20, the latter 14 SEZ [3]. Since SEZs aimed to contribute to the regional development processes, we can observe several types of them, such as medical technology, foreign business and innovation, electronics and electrical products, industrial production, ports or tourism and recreational SEZ [4].

In Hungary SEZ appears mostly as the Free Enterprise Zone (FEZ), since the act XXI of 1996 (the basis of the National Spatial Development Concept) states that the government can create enterprise zones for regional development purposes. These zones could be FEZ, which were coordinated by a regional economic development organization, bounded by administrative borders furthermore, the beneficiary areas, which have a highlighted economic sector, specified by the government from the national economic aspect. In 1996 the government defined FEZ in 8 areas of the country mostly near to the northern-eastern and the southern-western borderlines [5;6]. The close-toborder and peripheral location of this beneficiary (that is, enterprise zones) was formed caused by some special historical, economic, settlement network and social specificity of Hungary [7].

The 15/2018 regulation declares settlements located in development-needed or complex program needed beneficiary districts (Fig.1.) determined by the regulation 290/2014 and settlements disadvantageous in regional (economic) development and employment aspects. The regulation 290/2014 uses a different kind of indicators categorized in four different dimensions in order to define the beneficiary districts. The dimensions are connected with social and demographical situation, the housing and living circumstances, local economy and employment, and they are also related to infrastructure and environment. According to the results of the complex indicator the districts with the lowest score are the most disadvantageous ones. It means that practically the FEZs consist of the most lagging behind settlements, areas [8;9].

Another common characteristic of these disadvantageous (i.e. FEZ) areas is that - thanks to the before mentioned special historical and economic specificities - the agricultural sector plays a key role in their economic life and their development possibilities, which appears in spatial, regional or national development concepts as well. In the National Spatial Development Concept (1996) we can observe that several FEZ (beneficiary) areas are identified as "Agricultural rural development area". It shows well the mixture of the agricultural history aspects and the new, changed, EU harmonized theories [5]. In the regional research history (mainly from 1960-1990) of Hungary there are many studies dealing with the development-aimed agricultural based spatial division, which were driven by the growth of the productivity.

Latter studies and the development concept treated agriculture as a part of the rural development but not just in a classic way; a lot of new interpretations, such as diversification, agrotourism, rural tourism etc. were born. The role of the tourism has increased in the development policies and, besides the diverse agriculture, the policy makers attach a great importance to it especially in the peripheral, beneficiary areas [10]. The Act CLVI. of 2016 regulates the definition of the touristic regions completed with two regulations $(429 / 2016,140 / 2017)$, which determine the area of the touristic regions and also the area of the outstanding touristic development regions and specify the settlements belonging to them. The regulations treat the Balaton (with 174 settlements), the settlements of SopronFertö (15 + the area of the Fertö-Hanság National Park) and the settlements of Tokaj, Upper-Tisza and 
Nyírség (98) as an outstanding touristic development region. A lot of settlement belong to rural areas and appear both in the beneficiary and in the touristic region category [11].

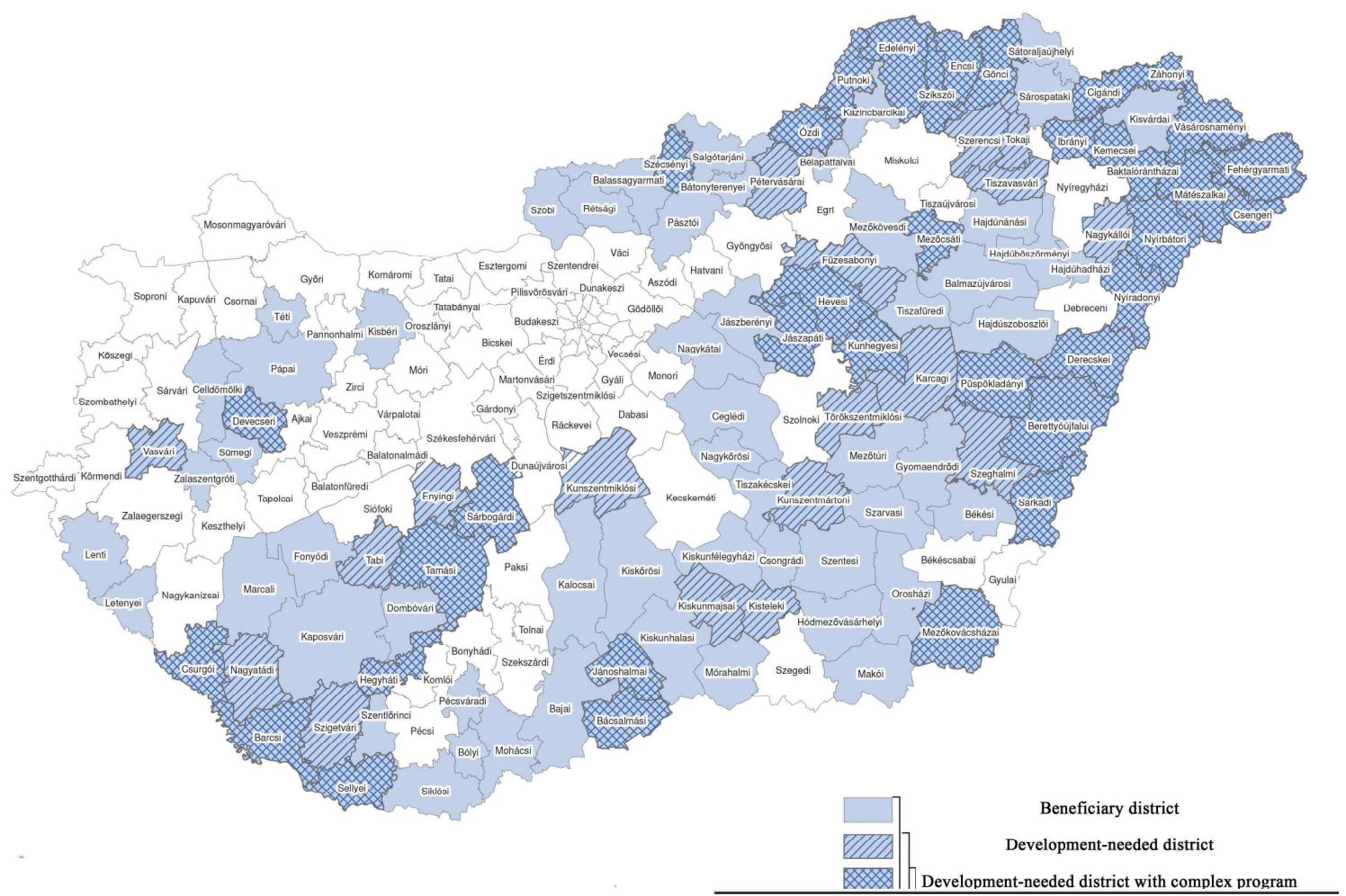

Fig. 1. Beneficiary districts in Hungary

From the urban (more developed) point of view another special zone designation exists, based on agglomerations - the intensive connection with the core urban areas with their neighbour settlements and requires to be handled together with the development aspects. These areas have a different type of characteristics from the rural, lagging behind (FEZ) territories, therefore, their development programs differ from the rural ones (for example, smart approaches often turn up in connection with urbanized areas in order to solve agglomeration disadvantages, but in the rural areas smart solutions are just in future plans [12]. However, in Fig.2 we can see that the Balaton region has been defined as an agglomerating area, even if several parts of its area are defined as an outstanding touristic region and many settlements belong to the development-needed districts at the same time [13].

The currently valid National Development and Spatial Development Concept decrees the operation of Regional Development Councils and defines the areas under the authorities of the councils based on the previous National Development Concepts. According to the regulation nowadays nine Regional Development Councils (RDC) are functioning, as we can see in Fig. 3. Two of them are outstanding development councils, namely, the Balaton Development Council and the Tokaj Wine region Development Council. (Notice: the Budapest agglomeration is an outstanding region as well, but it does not have an independent development organization.) We can observe that the jurisdiction areas of some councils are almost in line with the (outstanding) touristic regions' settlements (e.g., the Balaton, Sopron-Fertö ,Tokaj Upper-Tisza and Nyírség) and we can discover new elements, for example, the Duna-Tisza Köze Homokhátság RDC, which did not appear before. It is caused by the regulated operation and tasks of the councils. The concept determines the constitution of the council (the obligatory members in all cases are the presidents of the county councils and the representatives of the local economic and NGO are invitees) and regarding to the specialities of the area in question also the focused assignments. The Duna Tisza Köze Homokhátság RDC region has not primary touristic priorities, but agricultural, employment and economic related problems. It means that this initiative is based on a bottom-up approach, local needs and requirements [14]. 


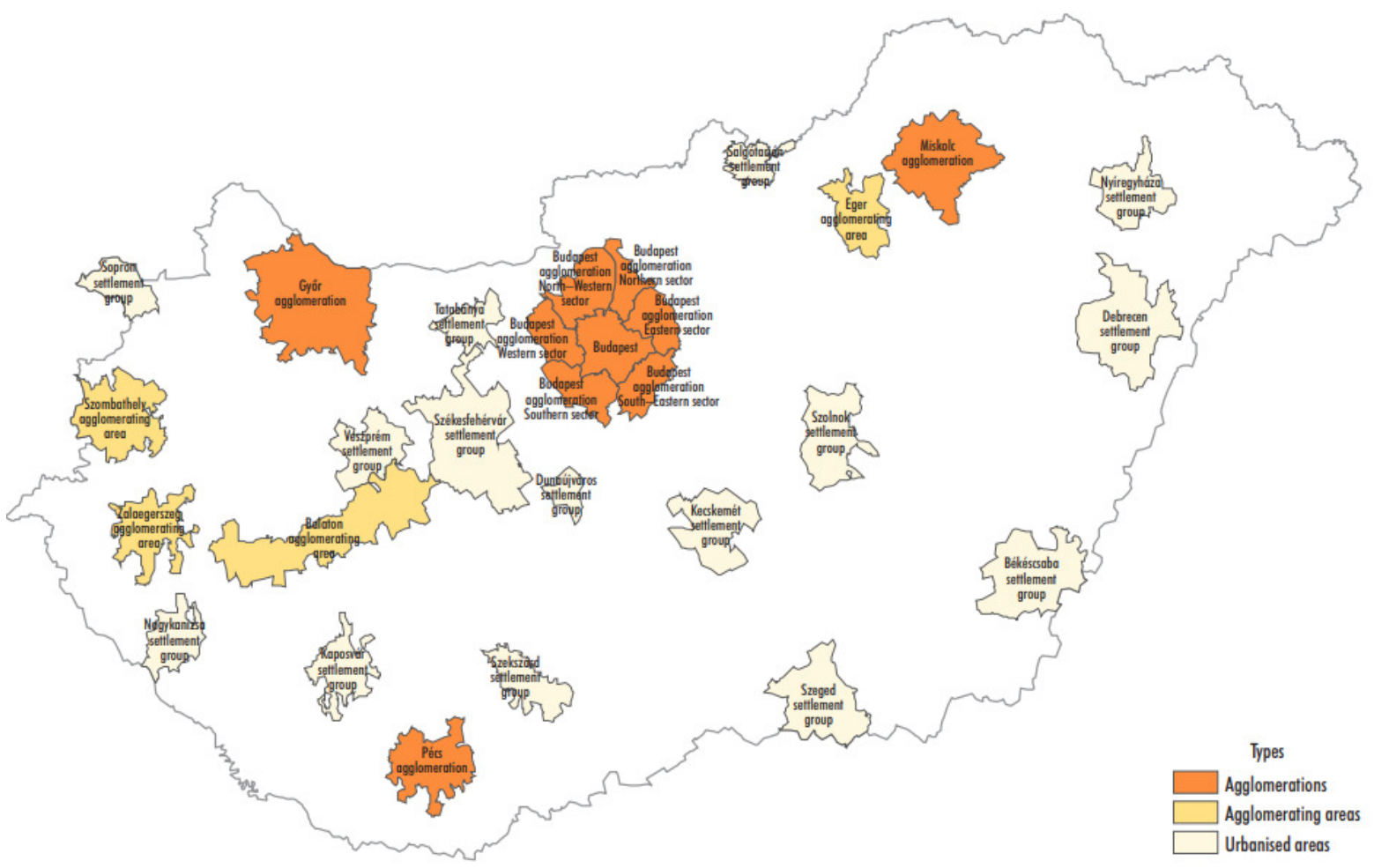

Fig. 2. Agglomerations, agglomerating areas, urbanised areas

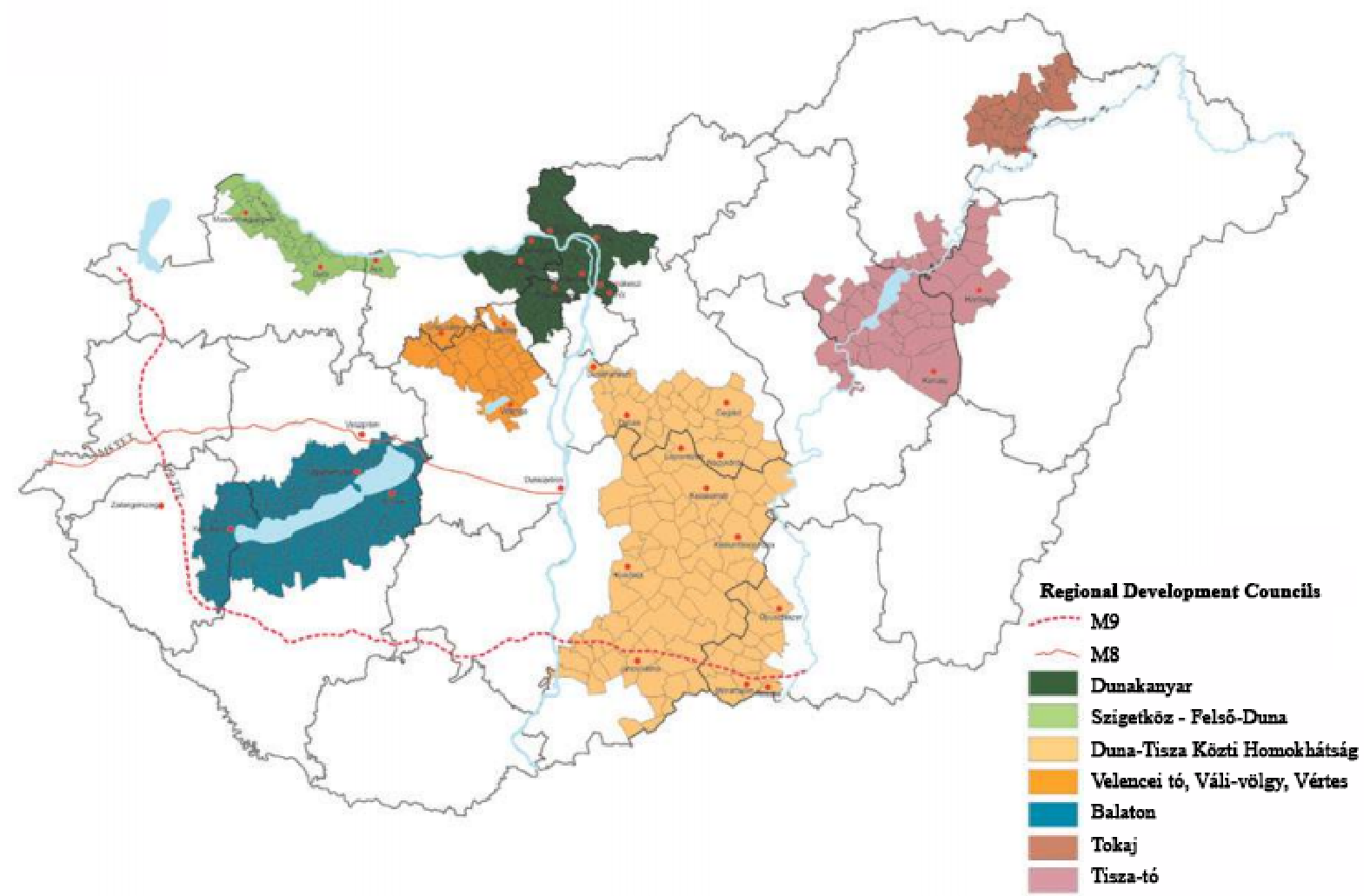

Fig. 3. Location and authority of Regional Development Councils

Only the LEADER initiation provides a development-aimed spatial division system, which covers almost the whole area of the country (Fig.4.) and guarantees that all subunits have a development policy. The LEADER community initiative was started by the European Commission in 1991. It relies 
on the collaboration of local public administration services, entrepreneurs and non-governmental organizations and gives them own decision making power along seven principles (regional based development, bottom-up approach, three-sided partnership, innovation, integrated inter-sectoral approach, operating network, cooperation). It creates settlement groups in coherent geographical rural areas with 10-100 thousand inhabitants for elaboration and implementation of the Local Development Strategies [15]. These groups are called Local Action Groups. The theory behind the initiative is very similar to the American example about the Economic Development Districts, the difference is in the order of the actions. In the USA the members of the EDD can decide independently to build up a district together and create a common strategy, otherwise in the case of the LEADER program the members are categorized by the number of inhabitants, therefore the sphere of the collaborates is given.

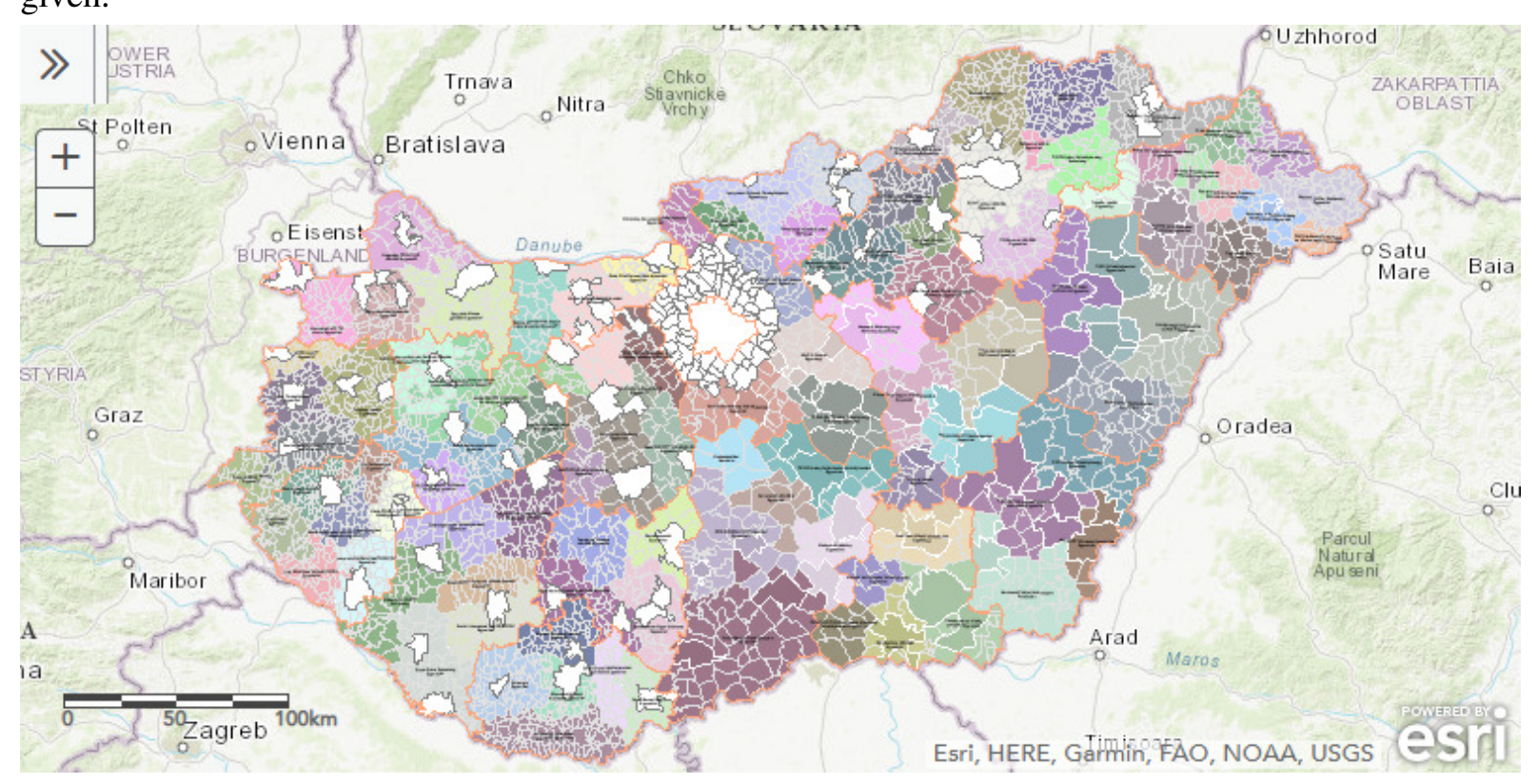

Fig. 4. LEADER Local Action Groups 2014-2020

\section{Conclusions}

1. We can conclude that formation of the development-aid spatial division systems has a long history in Hungary. The main problems are recognized, and as we could see, a wide range of possible solutions exist.

2. In order to create a new type of classification in the field of development district policy decision makers have to harmonize the already existing variables.

3. By the help of a complex indicator system (which bases are already used, for example, in formation of beneficiary regions, thus in the determination of FEZs and touristic regions) we could create a more effective, lower spatial level system, which considers the local specificities even within the larger categories.

4. We have to decide which pillar will be the hot point of the development; we cannot apply the same "generous" priorities to the whole designated development areas.

5. The next step is harmonization of the different development concepts for easier implementation and application of the defined principles in the case of the settlements (or smaller territorial units) that are a part of two or three development types at the same time.

6. The American example could be a good practice, if the confidence and the cooperate-willingness will work between the areas in question.

\section{Acknowledgements}

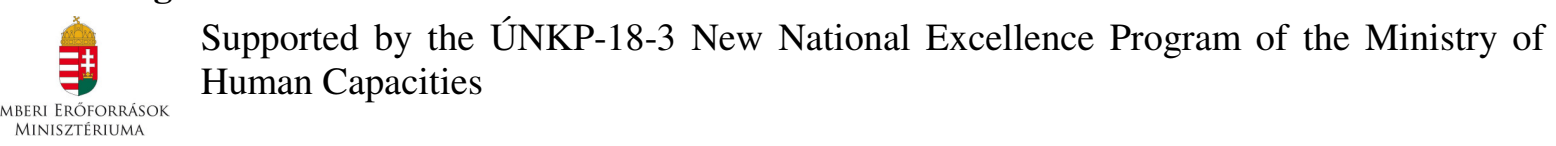




\section{References}

[1] Nemes Nagy J. Terek, helyek, régiók (Digitális kiadás.) Budapest, Akadémiai Kiadó 2017. (Spaces, places, regions, Akadémiai Publ., Budapest (in Hungarian) [online] [2019.02.22] Available at: https://eisz.mersz.org/?xmlazonosito = dj194thr_43_p1\#dj194thr_43_p1)

[2] U.S. Economic Development Administration. EDA Informational Brochure. 2017. [online][2019.03.04] Available at: https://www.eda.gov/pdf/about/EDA-trifold-2017.pdf

[3] Nagy H, Illés B., Káposzta J., Inna Donnik. Clusters and concentration of businesses in regions of some European countries as tools for economic development, Engineering for Rural Development, 2017, pp. 248-253

[4] Golubkin I., Bukharova M., Leonid Danilov L., et al. Russian Special Economic Zones: Business Navigator 2017. Association of Clusters and Technology Parks. - Moscow: AKIT, 2017. - 148 p. [online][2019.03.01] Available at: http://admin.ved.gov.ru/uploads/Business \%20Navigator \%20(1).pdf

[5] 1996. évi XXI. törvény. (Act XXI. of 1996. (In Hungarian) [online] [2019.02.28] Available at: https://net.jogtar.hu/jogszabaly?docid $=99600021 . \mathrm{TV})$

[6] Dankó L. A hazai különleges gazdasági övezetek fejlesztésének marketingsajátosságai. Marketing\&Menedzsment Vol. 32. No5. 1998. 26-30p. (The marketing specificity of the development of national special economic districts. The Hungarian Journal of Marketing and Management Vol. 32 No5. 1998. pp. 26-30. (In Hungarian))

[7] Pénzes J., Bujdosó Z., Dávid L., Radics Z., Kozma G. Differing development path of spatial income inequalities after the political transition - by the example of Hungary and its regions EKONOMIKA REGIONA / ECONOMY OF REGION 2014 : 12014 pp. 73-84.

[8] 15/2018. (II. 13.) Korm. rendelet a szabad vállalkozási zónák létrehozásának és müködésének, valamint a kedvezmények igénybevételének szabályairól szóló 27/2013. (II. 12.) Korm. rendelet módosításáról. Magyar Közlöny No.18. 2018 658-684p. (15/2018. Regulation on operation and creation of the Free Enterprise Zones and on the modification of the Regulation 27/2013 on the requisitioning of the benefits (in Hungarian)[online][2019.03.01] Available at: http://www.kozlonyok.hu/nkonline/MKPDF/hiteles/MK18018.pdf

[9] 290/2014. (XI. 26.) Korm. rendelet a kedvezményezett járások besorolásáról. (290/2014. (XI. 26.) Government Regulation on the classification of beneficiary districts. (in Hungarian) Magyar Közlöny No.56. 2015, 161., pp. 16172-16190.

[10] Dávid L.; Tóth G; Bujdosó Z.; Remenyik, B. The role of tourism in the development of border regions in Hungary, Romanian Journal of Economics 2011. 32 : 2, pp. 109-124.

[11] Áldorfainé Cz. L., Oláh I. The role and the importance of the economic districts in the regional development. Challenges in the Carpathian Basin Innovation and technology in the knowledge based economy. 2018 pp. 16-26.

[12] Káposzta J., Nagy H., Varga-Nagy A. Is ICT smartness possible development way for Hungarian rural areas? Engineering for Rural Development, 2018 pp. 463-469.

[13] Regional Atlas - Settlement groups, agglomerations, agglomerating areas. Hungarian Central Statistical Office [online][2019.03.02] Available at: http://www.ksh.hu/regional_atlas_agglomerations

[14] Kocsor K. Térségi Fejlesztési Tanácsok Magyarországon, Falu Város Régió. Nemzetgazdasági Minisztérium, Budapest, 2016 No.1. 9-14pp. (Regional Development Councils in Hungary, Village Town Region, Ministry for National Economy (In Hungarian))

[15]Lechner Nonprofit Kft. Térport. 2012. (Lechner Nonprofit Ltd. Spaceport (in Hungarian) [online][2019.02.27] Available at: http://www.terport.hu/videkfejlesztes/leader) 